\title{
Homeless Children and Youths in Lagos, Nigeria: Their Characteristics, Street Life and Sexual Behaviour
}

\author{
Patrick A. Edewor, Ph.D \\ Department of Sociology, Covenant University \\ P.M.B. 1023, Ota, Ogun State, Nigeria \\ E-mail: patrick.edewor@covenantuniversity.edu.ng, edeworpat@yahoo.com
}

\section{Doi:10.5901/mjss.2014.v5n1p537}

\section{Abstract}

This paper is based on a study carried out on homeless children and youths in Lagos, Nigeria. The study was aimed at understanding the characteristics, street life and sexual behaviour of homeless children and youths as well as the causes, problems and policy implications of homelessness. A survey of 447 homeless children and youths in three purposively selected parts of Lagos metropolis was done. The results show that majority of the respondents were males. They had low level of education and were from poor and large families most of which were polygynous. Parental neglect, discontent at home, marital instability in family of orientation, poverty and peer influence were the major causes of being on the street. They slept under bridges, at the beach, in motor parks and vehicles, in market places, and in uncompleted buildings. Their survival strategies include engaging in some income-yielding activities such as carrying load, being bus conductors, packing refuse, buying and selling, engaging in commercial sex and begging. Substance abuse and engaging in risky sexual behaviour were common. They faced the problem of insecurity, police harassment and all forms of exploitation and maltreatment from social miscreants (area boys). They were also predisposed to a number of hazards including sexual abuse, molestation and health hazards. The paper concludes by making recommendations for policy based on the findings.

Keywords: Homeless children, youths, street life, sexual behaviour, Lagos, Nigeria

\section{Introduction}

A common feature in many large cities in Nigeria, particularly in Lagos, is the presence of homeless children and youth, also known as "children of the street". These children work and live on the street. They are unlike other street children (children in the street) who normally return home to sleep at night (Ebigbo, 1988; Maduewesi, 1992). These homeless children have drifted from their homes or families of orientation, and they make the streets their homes. In the northern cities of Nigeria are found the Almajirai. These are children who are sent by Islamic tutors to beg in the street. Koranic education in northern Nigeria actually encourages this practice. In the cities of southern Nigeria, a few of such could also be found, but in this case, they serve as guides to physically handicapped adults, mostly their parents, especially the blind, as they engage in street begging.

A number of studies (Ebigbo and Izuora, 1985; Okpara, 1988; Oloko, 1988; Shindi, 1988; Ebigbo and Abaga, 1990) have examined various aspects and features of the activities of street children, particularly hawking and street trading. These studies have mainly focused on "children in the street", who are not necessarily homeless like "children of the street". Our focus in this study is not on street children in general but on those who work and live on the streets (the homeless children and youth).

Encarta (2004) has defined homelessness as the "condition of people who lack regular legal access to adequate housing". It is argued that a number of factors could bring about homelessness in general, including local or regional unemployment, war, racial discrimination, mental or physical disability, or indeed, a combination of factors. Although the United Nations has estimated the number of homeless people globally to be in excess of 1 billion, it is actually impossible to get the precise number. This is essentially because researchers define homelessness in different ways and also because of the transitory nature of the homeless. Whereas the homeless population in the West is largely made up of men, (though the proportions of women and children are steadily increasing), the homeless in Nigeria, particularly in Lagos, appear to be mainly male children and youth.

Evidence from literature shows that homelessness is predominantly an urban phenomenon. This is partly because of the commercialization of land and housing markets in the world's cities. Studies have shown that homelessness 
among families with children is increasing not only in low income countries but also in high income countries despite their affluence (National Coalition for the Homeless, 1999). It is also noted that the experience results in anxiety and depression for both children and parents, and can lead to the break-up of families as children are placed in foster care (UNICEF, 2002; National Coalition for the Homeless, 1999).

Although the phenomenon of children living on the street is peculiarly an urban one, many of the children involved may originate from rural areas (UNICEF, 2002). It has been suggested that possible reasons for leaving home may include abuse, a desire for excitement or relief from oppressive home conditions but they may become vulnerable to all forms of abuse and hazards on the street. They are most especially harmed by harsh physical conditions, violence and harassment, labour exploitation, absorption into criminal networks and denial of their right to receive an education that will equip them to achieve a better life (Richter, 1991). A lot of these homeless children engage in hazardous work on the street - for instance, dodging traffic as they sell goods to passing motorists. While many are engaged in legitimate work, others choose or are pushed into illegal activities including engaging in crime and theft, commercial sex or drug trade or becoming drawn into organized begging (UNICEF, 2002). They are often among the most stigmatized urban dwellers and they constantly face abuse from other persons and harassment from the police. They are often arrested for crimes or simply for vagrancy, and can be trapped for long months in the slow moving bureaucracy of the justice system, detained in conditions that violate their basic rights (UNICEF, 2002). Homeless children face extortion, theft, severe beatings, mutilation, sexual abuse and even death ${ }^{1}$. While in police custody, they may be forced to pay bribes in order to be released. The girls may be coerced into providing sexual services to police officers in exchange for release, or may be raped.

Homeless children and youth are denied access to basic human rights and are exposed to physical and sexual abuse, hunger and occasional hostile weather conditions (Campbell and Ntsabane, 1995). Most studies have focused on street children in general, and a number of factors are usually considered as the reasons for their being in the street. These include conflicts within the family; physical, emotional and sexual abuse; single parenthood, poor parenting, poverty, termination of education, child labour and peer influence (UNICEF, 1992; Campbell and Ntsabane, 1995; Aderinto, 2000). These studies were not strictly on homeless children and youth. They were on street children who may not necessarily be homeless. An understanding of the causes of homelessness among children and youth and relevant policy options must be based on relevant empirical study. It is against this backdrop that this study was undertaken. The broad objective of this study is to seek to understand the characteristics of homeless children and youth in Lagos, Nigeria, as well as the causes of homelessness and the relevant policy options that should be pursued. In specific terms, the objectives of this study include: (a) to examine the socio-demographic and background characteristics of homeless children and youth in the study area; (b) to investigate the factors which informed their decision to leave home and to settle on the street; (c) to examine their attitude toward school, their aspirations and career goals; (d) to understand their street life including their behaviour, challenges, problems and prospects as well as help needed; (e) to examine their sexual behaviour, knowledge of HIVIAIDS and measures taken to prevent sexually transmitted infections; and (f) to, based on the findings, make recommendations for policy which could be adopted to curb the problem of homelessness among children and youth with its concomitants. We recognize the fact that the definitions of a child, a youth and an adolescent vary according to culture and custom. We have adopted WHO definitions as found in Schenk and Williamson (2005). We have considered a child as an individual younger than 18 years; a youth, as a young person who falls between age 15 and 24; and an adolescent as an individual in the state of development between the onset of puberty and maturity, from age 10 through 19. From these definitions an overlap in the ages can be observed. Thus, the line of demarcation between a child and a youth is not clear cut. As a result of this, children were not demarcated from the youth in this study.

\section{Methods}

\subsection{The Study Area}

This study was carried out in Lagos, southwest Nigeria. The city is the largest in Nigeria. It was Nigeria's capital city until 1991 when the country's capital was relocated to Abuja, central Nigeria. Lagos, however, remains a large commercial centre, densely populated and with severe housing problems and heavy traffic congestion. Not only is it Nigeria's largest city, it is also the nation's chief port as well as an economic and cultural centre. It is located on the Gulf of Guinea and it

1 See "Children's Rights, Street Children" at Human Rights Watch, www.hrw.org/children/street.htm 
is built on several islands and adjacent parts of the mainland. Important districts of Lagos include the old city, now the commercial district, on western Lagos Island; Ikoyi Island, situated on the east of Lagos Island; Apapa, the chief port district, on the mainland; low-lying Victoria Island; industrialized Iddo Island; and a group of mainland suburbs (incorporated as part of the city in 1967), Ebute Meta, Yaba, Suru-lere, Mushin, and Ikeja. Thus, the city occupies Lagos Island, Ikoyi Island, Victoria Island as well as a large area on the mainland. All these are connected by a series of bridges and major roads.

Although the Yoruba people constitute the city's major ethnic group, other groups from other parts of the country as well as nationals from neighbouring countries are also to be found in the city. The diverse and fast growing population is a consequence of the ongoing migration from other parts of the country as well as from neighbouring countries. It is the most populous city in Nigeria with an estimated population of 13,427,000 in 2000 (Encarta, 2004). Not only is Lagos Nigeria's largest city, indeed, it is Africa's largest city. More than half of the country's industrial capacity is located in the city's mainland suburbs, particularly in the Ikeja industrial estate. The fact that the city is linked by rail and road to Ibadan, Kano and other major Nigerian cities makes movement to the city from other Nigerian cities relatively easy. At the end of the 1967-1970 civil war in Nigeria, Lagos witnessed an influx of refugees from neighbouring countries and it is still experiencing population boom. The city is now one of the world's largest urban centres. Traffic congestion on the city's roads is one of the most severe in the world and this leads to high level of air pollution and noise (Edewor, 2007). The movement of the nation's capital from Lagos to the central Nigeria city of Abuja in 1991 was an attempt by the Nigerian government to slow down the rate of growth of Lagos and to reduce its congestion. However, this move barely reduced the rate of growth (Edewor, 2007).

\subsection{Data Collection and Analytical Procedures}

Owing to the nature of the study, we adopted a sampling technique which we considered appropriate for the study. In the first instance, there is no sampling frame for the homeless children and youth in Lagos. Also, the exact number of homeless children and youth was not known at the time of study. However, we knew that homelessness among children and youth was a common feature in Lagos. What was then done was that we tried to identify the areas in which they could be found in large numbers. By the nature of the study, it became apparent that a purposive sampling technique would be the most appropriate. Even though homeless children and youth could be found in many parts of the Lagos metropolis, we chose the places where we felt they could be found in large numbers. These include Oshodi in the mainland suburb, Koramo Beach in Victoria Island, and ljora 7-up in Apapa. In each of the places, we chose to use the snowball method and each successfully interviewed respondent was asked to show us another homeless child or youth. Sometimes we saw them in groups but they were interviewed individually.

A 47-item interview schedule divided into four main sections was our research tool. The first section was on the socio-demographic characteristics of the respondents such as the location, sex, age, nationality, ethnic group, religion and educational level. The second was on their background information comprising questions on father's level of education, number of father's wives, number of mother's living children, whether parents were still together as husband and wife, whether both parents were still alive and where they live as well as father's occupation. The third section consisted of questions on the street life and the questions here had to do with how long and the age at which the child left home, the reason for leaving home, whether they would like to return home, where they normally sleep as well as their survival strategies. There were also questions on their perceived advantages, disadvantages and dangers of being on the street, their future ambitions as well as questions on substance abuse. The final section comprised of questions on their sexual behaviour, the major problem they are facing now as well as the most important area in which they need help now.

Personal interview method was adopted. Twenty five final year students of sociology at Covenant University, Ota, who had just completed two courses on methods of social research and 3 graduate assistants in the departments sociology and human resource development of the same university were trained and recruited for the data collection exercise. The researcher personally supervised the field work. Owing to the large number of interviewers, the exercise was completed in two days. At the end of the exercise, 475 respondents were successfully interviewed. The administered interview schedules were edited after which 447 were adjudged usable for analysis. Data entry was done and the SPSS was used for analyses. Analyses performed include frequency distribution for all variables and other descriptive statistics such as computation of means and standard deviation for the interval level variables. 


\section{Results}

\subsection{Socio-demographic and background characteristics}

The first part of this sub-section is on the socio-demographic characteristics of the respondents while the second is on their background characteristics. The socio-demographic characteristics cover the location, sex, age, nationality, ethnic group, religion and educational level (see Table 1). Two-fifths of the respondents were located in Oshodi, and 30 percent and 29 percent were located in Koramo Beach and ljora 7-up, respectively. These locations and other places where homeless children could be found in Lagos have some peculiar features; they are close to a market, a motor park and a major bridge. Only Koramo Beach is, however, different in that there is neither a market nor motor park nor bridge. It is located at the shore of the Atlantic Ocean. Many omo sa nle (children who have run away from home, as they are called in the Yoruba language) settle at this beach.

Majority of the homeless children and youth were male (84 percent) and they were mainly between age 15 and 19; the mean age was 18.75 years. An overwhelming majority (97 percent) was of the Nigerian nationality and they were mainly of the Yoruba ethnic group. Fifty four percent were adherents of the Islamic religion while about two-fifths were of the Christian faith. With respect to the level of education, more than half had either no formal education or had only primary education. Although 44 percent claimed to have attended secondary school; majority of this number dropped out of secondary school. Ninety two percent of the respondents were not currently in school. Majority (68.1 percent) gave financial reason or poverty as the reason for not being in school. Other reasons include lack of interest (8 percent), parent(s) deceased (5.2), parental neglect (3 percent), conflict with parents (1.9 percent) and a few other reasons.

Table 2 presents the distribution of the respondents by background characteristics. Here, we tried to examine their father's level of education, the form of marriage in their family of orientation, number of mother's living children, whether parents were still together as husband and wife, whether both parents were still alive as well as father's occupation. The essence of the background information was to gain insight into the kind of family settings into which they were born and possibly the kind of upbringing they must have had.

Quite unexpectedly, about half of the respondents had fathers with secondary or more education. Only two-fifths had fathers with primary or less education. About 63 percent were from polygynous homes and a little over half had mothers with at least five living children. Majority (63 percent) were from homes with marital disruptions. When asked whether their parents were still together as husband and wife, it was observed that only 37 percent answered in the affirmative. Of the rest who answered otherwise, 47.6 percent had parents who were either separated or divorced, and 39 percent had one parent deceased (not shown in Table). On the whole, however, 63 percent of all the respondents claimed that they have both parents alive. About one-tenth have lost both parents, while 27 percent had only one parent alive.

With respect to father's occupation, about half had fathers who were engaged in skilled manual jobs or farming. Only a dismal few had fathers who were engaged in higher professional or higher commercial occupations ${ }^{2}$ This establishes the low status background of the respondents. Besides the low status background, the polygynous family background coupled with the high fertility of respondents' mothers creates a condition in which children may be denied the required parental care. In Nigeria, polygynous men normally abandon their children to their respective mothers. Consequently, polygynously married women bear higher costs of childrearing than do their counterparts in monogamous unions (Edewor et al, 1997; Edewor, 2001).

\footnotetext{
2 Details of the occupation groupings are as follows: farming (crop production, livestock farming, fishing and hunting); skilled manual (mechanics, drivers, carpenters, tailors, draughts men, vulcanizers, brick-layers, etc); clerical and allied (clerks, typists, book-keepers, cashiers, etc); higher commercial (owners or managers of big businesses or operators of supermarkets); lower commercial (owners of small shops, petty traders, shop assistants, rent collectors, hawkers, etc); higher professional (doctors, lawyers, pharmacists, army officers, university lecturers, school principals, etc); lower professional(teachers, clergymen, policemen, nurses, welfare officers, etc); other (miscellaneous and unclassifiable, including the retired, unoccupied, etc).
} 
Table 1: Distribution of respondents by socio-demographic characteristics.

\begin{tabular}{|c|c|c|}
\hline $\begin{array}{l}\text { Socio-demographic } \\
\text { Characteristic }\end{array}$ & $\mathbf{N}$ & Percent \\
\hline \multicolumn{3}{|l|}{ Location } \\
\hline Oshodi & 183 & 40.9 \\
\hline Koramo Beach & 134 & 30.0 \\
\hline Ijora 7-up & 130 & 29.1 \\
\hline Total & 447 & 100.0 \\
\hline \multicolumn{3}{|l|}{ Sex } \\
\hline Male & 375 & 83.9 \\
\hline Female & 72 & 16.1 \\
\hline Total & 447 & 100.0 \\
\hline \multicolumn{3}{|l|}{ Age } \\
\hline$<15$ & 63 & 14.1 \\
\hline $15-19$ & 211 & 47.2 \\
\hline $20-24$ & 139 & 31.1 \\
\hline $25+$ & 34 & 7.6 \\
\hline Total & 447 & 100.0 \\
\hline Mean & Std. Dev. $=4.18$ & \\
\hline \multicolumn{3}{|l|}{ Nationality } \\
\hline Nigerian & 434 & 97.1 \\
\hline Other & 13 & 2.9 \\
\hline Total & 447 & 100.0 \\
\hline \multicolumn{3}{|l|}{ Ethnic group } \\
\hline Yoruba & 310 & 70.1 \\
\hline Hausa & 49 & 11.1 \\
\hline Igbo & 34 & 7.7 \\
\hline Other & 49 & 11.1 \\
\hline Total & 442 & 100.0 \\
\hline \multicolumn{3}{|l|}{ Religion } \\
\hline Christianity & 194 & 43.4 \\
\hline Islam & 241 & 53.9 \\
\hline Traditional religion & 7 & 1.6 \\
\hline Other & 5 & 1.1 \\
\hline Total & 447 & 100.0 \\
\hline \multicolumn{3}{|l|}{ Educational level } \\
\hline No formal education & 60 & 13.4 \\
\hline Primary & 178 & 39.8 \\
\hline Secondary & 197 & 44.1 \\
\hline Tertiary & 8 & 1.8 \\
\hline Other & 4 & 0.9 \\
\hline Total & 447 & 100.0 \\
\hline
\end{tabular}

Table 2: Distribution of respondents by background characteristics

\begin{tabular}{|c|c|c|}
\hline $\begin{array}{l}\text { Background } \\
\text { Characteristics } \\
\end{array}$ & $\mathbf{N}$ & Percent \\
\hline \multicolumn{3}{|c|}{ Father's educational level } \\
\hline No formal education & 107 & 24.2 \\
\hline Primary & 71 & 16.1 \\
\hline Secondary & 115 & 26.0 \\
\hline Tertiary & 104 & 23.5 \\
\hline Other & 45 & 10.2 \\
\hline Total & 442 & 100.0 \\
\hline \multicolumn{3}{|c|}{ Father's form of marriage } \\
\hline Monogamy & 164 & 37.2 \\
\hline Polygyny & 276 & 62.8 \\
\hline Total & 440 & 100.0 \\
\hline Mean no. of wives & Std. Dev. $=3.40$ & \\
\hline \multicolumn{3}{|l|}{ Mother's living children } \\
\hline$<5$ & 216 & 48.6 \\
\hline $5+$ & 228 & 51.4 \\
\hline Total & 444 & 100.0 \\
\hline Mean & 4.86 children $\quad$ Std. Dev. $=2.56$ & \\
\hline \multicolumn{3}{|l|}{ Are parents still married? } \\
\hline Yes & 163 & 36.6 \\
\hline No & 282 & 63.4 \\
\hline Total & 445 & 100.0 \\
\hline \multicolumn{3}{|l|}{ Are both parents alive? } \\
\hline Yes & 279 & 62.7 \\
\hline No & 46 & 10.3 \\
\hline Only one parent alive & 120 & 27.0 \\
\hline Total & 445 & 100.0 \\
\hline \multicolumn{3}{|l|}{ Father's occupation ${ }^{2}$} \\
\hline Farming & 45 & 11.8 \\
\hline Skilled manual & 148 & 38.8 \\
\hline Clerical and allied & 22 & 5.8 \\
\hline Higher commercial & 6 & 1.6 \\
\hline Lower commercial & 59 & 15.5 \\
\hline Higher professional & 18 & 4.7 \\
\hline Lower professional & 47 & 12.3 \\
\hline Other & 36 & 9.4 \\
\hline Total & 381 & 100.0 \\
\hline
\end{tabular}




\subsection{The street life}

It was observed that one-third of the children and youth had been homeless for four or more years. Another 31 percent left home in less than one year while the rest had left home for a period of between one and three years. The mean age at which they left home was 15.4 years. The reasons frequently given for leaving home range from "financial problem", "in search of job", "maltreatment", "neglect or lack of care", "conflict with parent", "parents deceased", "peer influence", to "parents divorced", in that order (See Table 3). The fact that financial problem was mentioned most frequently as the reason for leaving home underscores the fact that poverty is a very important predisposing factor to homelessness among children and youth. The effect of poverty will be particularly felt especially that majority of them were from polygynous homes and from large families. In spite of the conditions that led to their leaving home, majority (82 percent) expressed their desire to return home especially if the problems that led to their leaving home could be solved. More than half of the children claimed that their parents do not know their whereabouts because they never informed anyone of when and where they were going. The children sleep mainly under bridges, at the beach, in motor parks and vehicles, in markets, in uncompleted buildings and in the bush but particularly under bridges, at the beach, motor parks and vehicles as well as in the markets. They engage in some survival strategies including carrying loads, being bus conductors, packing refuse, buying and selling, prostitution (about half of the females among them engaged in prostitution) and begging, in that order (See Table 4). Even though half of the respondents did not see any advantage in living on the street, a quarter

Table 3: Distribution of respondents by reason for leaving home

\begin{tabular}{lcc}
\hline Reason & N & Percent \\
\hline Financial problem & 168 & \\
Maltreatment & 42 & 39.0 \\
In search of job & 45 & 9.7 \\
Conflict with parents & 25 & 10.4 \\
Parents divorced & 7 & 5.8 \\
Parents deceased & 23 & 1.6 \\
Child abuse/labour & 12 & 5.3 \\
Neglect/lack of care & 26 & 2.8 \\
Peer influence & 12 & 6.3 \\
No reason & 27 & 2.8 \\
Other & 44 & 6.3 \\
Total & 431 & 10.2 \\
\hline
\end{tabular}

and 16 percent respectively saw the money they were able to make on their own and the freedom they have as advantages. However, insecurity, extortion and harassment from area boys ${ }^{3}$ suffering, police harassment, accommodation problem, severe beatings, molestations,

Table 4: What homeless children and youths do for a living (Survival strategies).

\begin{tabular}{llc}
\hline Survival strategy & N & Percent \\
\hline Carrying load & 130 & 29.2 \\
Packing refuse & 53 & 11.9 \\
Conductor & 96 & 21.6 \\
Prostitution & 31 & 7.0 \\
Begging & 16 & 3.6 \\
Buying and selling & 37 & 8.3 \\
Other & 82 & 18.4 \\
Total & 445 & 100.0 \\
\hline
\end{tabular}

health hazards and lack of food in that order, feature prominently in what they considered the disadvantages of being homeless. Similar responses were also given as the major dangers they face but with police harassment, extortion and harassment from area boys as well as beatings and fighting, in that order, being the most frequently mentioned. Sexual abuse in the form of rape and sexual harassment were the most frequently mentioned disadvantages and dangers by

${ }^{3}$ Area boys are the social miscreants found on the streets. They are much older and fierce-looking and they are usually engaged in substance abuse particularly the use of marijuana and in street fights. Many homeless children grow up to become area boys. 
female children and youth. About half of the females admitted having been raped, sexually molested or harassed. These underscore the amount of hazards they are exposed to. With respect to substance abuse, 36 percent and a quarter, respectively, admitted smoking cigarette and taking marijuana. We, however suspect, judging from what we observed on the field, that these may have been under reported, particularly the use of marijuana, owing to the general societal disapproval of its use in Nigeria. From what we saw on the field, substance abuse, particularly the use of marijuana was very common especially among the older ones. Thirty eight percent also admitted taking alcohol.

In spite of the fact that these children and youth are living on the street, and 92.4 percent are currently not in school, 88.1 percent expressed the desire to return to school; the rest are those who prefer to learn a trade. Despite their low level of education and present condition, they aspire to become something important in life as can be seen from their response to the question on what they will like to become in future. Table 5 shows the distribution according to their response. As can be seen in the table, a total of 36.6 percent aspire to pursue some higher occupational careers such as being a medical doctor, a lawyer, an engineer, an accountant and a pilot. Being a business man/woman or being a trader; an artisan; a soldier; a president, governor or a politician also feature prominently.

Table 5: Distribution of respondents by what they would like to become in future.

\begin{tabular}{lcc}
\hline What they would & N & Percent \\
Like to become & 50 & 12 \\
\hline Doctor & 39 & 9.4 \\
Lawyer & 37 & 8.9 \\
Engineer & 17 & 4.1 \\
Accountant & 57 & 12.7 \\
Business man/woman & 5 & 1.2 \\
Manager & 30 & 7.9 \\
Soldier & 10 & 2.4 \\
Police man & 25 & 6.0 \\
President/Govemor/Politician & 42 & 10.1 \\
Artisan & 12 & 2.9 \\
Footballer & 9 & 2.2 \\
Musician & 6 & 1.4 \\
Pastor/Evangelist & 2 & 0.5 \\
Imam & 64 & 15.3 \\
Other & 417 & 100.0 \\
Total & &
\end{tabular}

\subsection{Sexual Behaviour}

Just like substance abuse, homeless children and youth normally engage in risky sexual behaviour. Sixty percent of our sample was sexually active. This number was further asked to state the number of sexual partners they had, the age at which they first had sex, the number of times they had sex in the last one month, the number of persons with whom they had sex in the last one month, and the number of persons with whom they had ever had sex (See Table 6). As the Table shows, the children and youth have multiple sexual partners and the mean age at which they first had sex was 14.03 years. The mean number of times and persons with whom they had had sex in the last one month is 4.47 and 1.97 respectively. The mean number of persons with whom they have ever had sex is 6.64 . It should be noted that this figure is for only those who gave numerical answers. Those who simply said "many" or "I can't remember" or "I have lost count" were

Table 6: Distribution of respondents by sexual behaviour.

\begin{tabular}{lccc}
\hline Behaviour & Mean & Std. Dev. & N \\
\hline Number of sexual partners & 3.12 & & \\
Age at first sex & 14.03 & 3.88 & 226 \\
No. of times had sex in last 1 month & 4.47 & 3.62 & 270 \\
No. of persons with whom had sex & & 7.53 & 234 \\
$\quad$ in last 1 month & 1.97 & 1.97 & 239 \\
No. of persons with whom ever had sex & 6.64 & 11.70 & 178 \\
\hline
\end{tabular}

excluded. This suggests that the mean number of sexual partners they are currently having or they have ever had is likely to be higher. Of those who are sexually active, 21 percent had sex with a commercial sex worker the last time they did; 55 percent, with girl/boyfriend; 8.4 percent with a neighbour and the rest 15.7 percent with some other persons.

Majority (85.6 percent) knew of HIVIAIDS but only 58.4 percent of those sexually active use condoms to prevent 
contracting sexually transmitted infections, 9.4 percent claimed that they keep to one sexual partner but a quarter simply don't do anything to ensure that they do not contract sexually transmitted infections. We, are however, not sure whether those who claimed they use condom do so always and whether they also use it correctly. Our data show that three-fifths of those sexually active have multiple sexual partners and given this level of risk, this has serious implication for their reproductive health particularly in the era of HIVIAIDS.

\section{Discussion and Conclusion}

This study has shown that the homeless children and youth have a low level of education and many dropped out of school for financial reasons. Even though majority expressed the desire to return to school, their poor status background is a serious impediment. Poverty clearly stood out as a major factor that accounts for the present condition of these homeless children and youth. Besides, poverty, polygyny, marital disruption in family of orientation and large family sizes, are major background characteristics of the homeless children and youth. The low status and polygynous family background coupled with the high fertility and marital disruptions may have created a condition in which the respondents must have received inadequate parental care. These are fundamental issues that the society has to address.

The street life is such that the children and youth are exposed to considerable amount of hazards and they face a number of problems ranging from financial problems to harassment and extortions from police and social miscreants popularly known as area boys, insecurity, severe beatings and fighting, sexual abuse (especially of the females) and health hazards. We concede to Agnelli (1986) and Richter's (1989) claim that the presence of street children (and homeless children and youth) is an indictment of the way the society construes its priorities. These children and youth suffer considerable amount of hardship. Although they are ignored by the society, they hope to become productive members of the society.

There is the need to adopt approaches that would address fundamental issues such as how to prevent homelessness among children and youth as well as how to ameliorate the already existing situation. The involvement of individuals as persons becomes germane. This is because the human factor is very crucial in the successful implementation and execution of any programme that may be put in place. For there to be any meaningful success in dealing with the problem of homelessness among children and youth, individuals as persons have to understand the enormity of the problem at hand and have to be personally convinced of the need to pursue the cause of children and youth. This, to us, is the first step in the right direction because the stumbling block of human unwillingness to take implementation steps would be circumvented.

Given the fact that poverty plays a significant role in homelessness, at least from this study, concerted effort should be made to reduce unemployment, underemployment and alleviate poverty in our cities. In the same vein, efforts should be made to discourage polygyny among the different ethnic and cultural groups in Nigeria. Polygyny is associated with marital conflicts and instability. When there is divorce and remarriage, children born into the first marriage often do not fit in with the new arrangement. They soon fall out of favour with the new wife or with their father and eventually decide to leave home for the street. A reduction in polygyny will, therefore, reduce the decision to leave home.

There is the need to empower the family as a social institution, through marriage counseling and family life education, for effective socialization of children, bearing in mind the fact that what a child learns during his formative years becomes vital in his personality development. Closely related to this is the issue of high fertility. Homeless children and youth in Nigeria are mainly from large families. In this regard, the pursuance of aggressive family planning programmes to reduce the present high level of fertility is imperative.

The high degree of extortion and exploitation and abuse of homeless children testify eloquently to the gross violation of their human rights. This calls for an urgent need to protect the right of the homeless child. The judiciary and the law enforcement agencies need to understand the problems of the homeless persons so that their sympathy can be engaged. The need to improve the access of children to education cannot be overemphasized. Also, there is the need to intensify education on the danger of engaging in risky sexual behaviour such as having multiple sexual partners, and having unprotected sex or engaging in commercial sex. Closely related to this is also the need to step up efforts to eliminate substance abuse. The involvement of governmental and Non Governmental Organizations (NGOs) as well as religious bodies would be useful in this regard. Finally, more research should be carried out on homeless children and youth in Nigerian cities especially in Lagos and Port Harcourt. This would provide the basic descriptive information that could assist in putting in place the relevant programmes that would reduce the problem of homelessness among children and youth. In this regard, funding and other assistance could be sought from national governments and international bodies such as UNICEF, UNFPA, UNDP, ILO, World Bank, USAID as well as national NGOs. 


\section{References}

Aderinto, A. A. (2000). "Social correlates and coping measures of street children: a comparative study of street and non-street children in south-western Nigeria", Child Abuse Negl., September, 24 (9): 1199-1213. http://www.ncbi.nlm.nih.gov/entrez lquery.fcgi?cmd=Retrieve\&db=PubMed\&list uids=11057706\&dopt=Abstract

Agnelli, S. (1986). Street children: A growing urban tragedy. London: Weidenfield \& Nicolson.

Campbell, E. K. \& Ntsabane, T. (1995). Street children in Gaborone, Botswana: Causes and Policy implications, Darkar: UAPS, Small grants programme on population and development, Summary report, Number 13, July.

Ebigbo, P. O. \& Izuora, G. I. (1985). "Child labour in market places in Enugu: Socio-economic background", in Bwibo and Onyango (eds) Children in especially difficult circumstances, Nairobi: City Printing Works.

Ebigbo, P. O. (1988). "Child abuse and neglect: General information", ANPPCAN Advocacy Series I, Enugu: Chuka Printing Company.

Ebigbo, P. O. \& Abaga, B. (1990). "Sexual experiences of street trading girls in the city of Enugu". Paper presented at the $8^{\text {th }}$ International Congress on Child Abuse and Neglect, Hamburg, West Germany, 2-8 September.

Edewor, P. A.; Ademiluyi, I. A. \& Okosun, G. (1997). The value of children as a determinant of reproductive behaviour in Ogun State, Nigeria. A research report submitted to Population Research Fund (PRF), Nigerian Institute for Social and Economic Research (NISER), Ibadan.

Edewor, P. A. (2001). Fertility and the value of children among the Isoko of Delta State, Nigeria. Unpublished Ph.D thesis submitted to the University of Ibadan, Ibadan.

Edewor, P. A. (2007). "Residential segregation in Nigerian cities" in Sandhu, R. S. and Sandhu, J. (eds) Segregation in Globalizing Cities: Interface of Global Context and Local Structures in Developing Countries,New Delhi: Rawat

Publications.

Encarta (2004). "Lagos", in Encarta Encyclopedia, Microsoft Corporation.

Maduewesi, E. J. (1992). "The street children: The Nigerian case", in Nwabueze, N. and Oyekanmi, F. D. (eds) Social Problems and Social Policy in Nigeria, Lagos: Osko Associates.

National Coalition for the Homeless (1999). "Homeless families with children" NCH Fact Sheet No. 7, NCH.

Okpara, E. (1988). "Child labour as a significant index of poverty in Nigeria: Implications for social policy", in Ebigbo, P. O. et al (eds) Child Labour in Africa, Proceedings of the First International Workshop on Child Abuse in Africa, Enugu.

Oloko, B. A. (1988). "Children's domestic versus economic work and school achievement", in Ebigbo et al (eds) Child Labour in Africa, Proceedings of the First International Workshop on Child Abuse in Africa, Enugu.

Richter, L. (1989). South African street children: Comparisons with Anglo-American runaways. Pretoria: Unisa.

Richter, L. (1991). Street children in South Africa: General theoretical introduction. The Child Care World, 9, (9), 5-7.

Schenk, K. and Williamson, J. (2005). Ethical Approaches to Gathering Information from Children and Adolescents in International Settings: Guidelines and Resources. Washington, DC: Horizons, Population Council, Impact, Family Health International.

Shindi, J. (1988). "Parent loss and child labour in northern part of Nigeria", Child Labour in Africa, Proceedings of the First International Workshop on Child Abuse in Africa, Enugu.

UNICEF (1992). Children in especially difficult circumstance, UNICEF, Gaborone.

UNICEF (2002). Poverty and Exclusion among Children, Innocenti Digest, No. 10, November. 
